\title{
RELASI ISLAM DAN MULTIKULTURALISME DI INDONESIA
}

\author{
Mujib Ridlwan \\ Sekolah Tinggi Agama Islam Al Hikmah Tuban
}

\begin{abstract}
ABSTRAK
Fakta bahwa Islam dan budaya merupakan kekayaan bangsa Indonesia yang membanggakan, akhir-akhirini sedikit mengalami goncangan dan ancaman. Islam yang seharusnya hadir menjadi agama rahmatan lil alamin,dianggap sebagian anak bangsa bertentangan dengan budaya lokal. Oleh karena itu, tantangan pemeluk islam di Indonesia adalah bagaimana ajaran Islam dan kearifan budaya dapat berjalan seiring dan seirama. Tantangan ini mengharuskan pemeluk islam untuk menggali dalil-dalil dan fakta sejarah bahwa islam adalah agama rahmatan lil alamin, yang tidak bertentangan dengan kearifan budaya bangsa

Kata Kunci: Islam, Pendidikan Multikultural, Indonesia
\end{abstract}

\section{A. Pendahuluan}

Kehadiran paham multikulturalisme sebenarnya dilataribelakangi oleh realitas sosial tentang kemajemukan budaya yang terjadi di banyak belahan dunia, termasuk di Indonesia. Budaya dan keyakinan yang beragam, tetapi tidak menimbulkan efek negatif seperti pertikaian antar-ras, suku, dan budaya adalah sebuah kebutuhan mutlak bagi masyarakat di dunia. Lahirnya multikulturalisme, tidak lain adalah sebuah pengakuan terhadap kemajemukan budaya, agama, ras, dan suku.

Terdapat tiga istilah yang biasa digunakan dalam menggambarkan perbedaan ras, agama, dan budaya, bahasa, yakni istilah keragaman (diversity), pluralitas (plurality), dan multikultural 
(multicultura). ${ }^{1}$ Pluralitas sekedar mempresentasikan adanya kemajemukan (lebih dari satu), sedangkan multukulturalisme memberikan penegasan bahwa dengan segala perbedaannya itu itu mereka adalah sama di dalam ruang publik.

Karenanya, multikulturalisme harus dipahami sebagai sebuah ideologi yang menjadi alat sekaligus wahana untuk meningkatkan penghargaan atas keseteraan semua manusia yang diwujudkan melalui pranata-pranata sosial. Azyumardi Azra mendefinisikan, multikulturalisme adalah pandangan dunia yang kemudian dapat diterjemahkan dalam berbagai kebijakan kebudayaan yang menekankan penerimaan terhadap realitas keagamaan, pluralitas, dan multikultural yangterdapat dalam kehidupan masyarakat. Multikulturalisme dapat juga dipahami sebagai pandangan dunia yang kemudian diwujudkan dalam kesadaran politik. ${ }^{2} \mathrm{Hal}$ ini berarti konsep multikulturalisme memberikan kontribusi besar terhadap agenda demokratisasi dan antidiskriminasi. Semua manusia, meskipun berbeda agama, ras, bahasa, dan suku, tetapi konsep multikulturalisme memberikan tempat yang sama dalam ruang publik.

Menurur Bhikhu Parekh ${ }^{3}$, gerakan multikulturalisme sebenarnya baru belakangan muncul, sekitar tahun 1970-an muncul pertama kalinya di Kanada dan Australia, kemudian disusul di Amerika Serikat,

\footnotetext{
${ }^{1}$ Pluralitas mengandalkan hal-hal yang lebih dari satu (many); keragaaman (diversity) menunjukkan bahwa keberadaan yang lebih dari satu itu berbeda-beda, heterogen, dan bahkan tak dapat disamakan. Sadangkan multikulturalisme adalah kesediaan menerima kelompok lain secara sama sebagai kesatuan, tanpa mempedulikan perbedaan budaya, etnik, jender, bahasa, ataupun agama. Gurpreet Mahajan, Demokracy, Difference and Justice. Terj.. (Jakarta:Lahore: Longman and Co, 1998), 37.

${ }^{2}$ Azyumardi Azra, Identitas dan Krisis Budaya: Membangun Multikulturalisme Indonesia, 2017, http://www.konggresbud.budpar.go.id.

${ }^{3}$ Bhikhu Parekh, lahir 4 Januari 1935 (82 tahun) di Amalsad, India. Pendidikannya ditempuh di Universitas Mumbai, London School of Economics Politikcal Science. Profesor Filsafat Politik di University of Westminster.Dia mengajar di University of Hull sejak 1964, dan juga seorang profesor tamu di beberapa institusi internasional.Dia adalah Wakil Ketua Komisi untuk Racial Equality (Kesederajatan Ras) dari tahun 1985 sampai 1990,dan memimpin Komisi Masa Depan Multi-Etnis Inggris, yang laporannya (Laporan Parekh) diterbitkan pada tahun 2000. Dia juga telah menulis sepuluh buku terkenal tentang politik Filsafat yang telah diterjemahkan ke dalam 15 bahasa. (https://www.hull2017.co.uk/theboard/professor-lord-bhikhu-parekh).
} 
Inggris, Jerman. ${ }^{4}$ Menurutnya, multikulturalisme paling baik dipahami bukan sebagai doktrin politik dengan konten programatik atau sekolah filosofis dengan teori tempat manusia yang berbeda di dunia tetapi sebagai perspektif atau cara untuk melihat kehidupan manusia. Gerakan multikulturalisme, belakangan telah memunculkan banyak tokoh, diantaranya, Mohammed Abed al-Jabiri, Hassan Hanafi, Nasr Hamid Abu-Zaid, mereka berupaya untuk melakukan rekonsiliasi antara tradisi dan agama. Tetapi gagasan-gagasan mereka tidak mulus, mendapatkan tantangan keras dari ulama-ulama konservatif, yang beranggapan bahwa agama dan tradisi itu tidak bisa disandingkan.

Sebelumnya, kaum fungsionalis juga melihat hal serupa, bahwa agama memiliki fungsi untuk membangun solidaritas sosial. Salah satunya disampaikan oleh Durkheim, yang melihat fungsi agama untuk menyatukan anggota masyarakat. Agama bisa memenuhi kebutuhan masyarakat untuk secara berkala -menegakkan dan memperkuat perasaan ide-ide kolektif. Tetapi di sisi lain, agama juga bisa menjadi penyebab konflik, dengan contoh konflik antara kaum Katolik dan kaum Protestas di Irlandia Utara, antara kaum Sikh dan kaum Hindu di Negara Bagian Punjab, antara kaum Muslimin dan jaum Hindu di Ayodhya. Bagaimana sebenarnya pandangan Islam terhadap multikulturalisme, serta bagaimana praktek multikulturalisme di Indonesia. ${ }^{5}$

\section{B. Tradisi \& Islam: Relasi Konfrontatif atau Kompromistik?}

Prinsip multikulturalisme yang memberikan penghargaan atas keseteraan semua manusia yang diwujudkan melalui pranata-pranata sosial adalah tidak bertentang dengan ajaran-ajaran agama Islam.

\footnotetext{
${ }^{4}$ http://www.psbps.org/index.php?option=com_conten\&task, postes 12 November 2008. ${ }^{5}$ Nanang Martono, Perubahan Sosial: Perspektif Klasik, Modern, Posmodern, dan Poskolonial, (Jakarta: Rajawali Pers, 2016), 306-308.
} 
Namun demikian, basis teorinya masih tetap mengalami masalah. Nilai-nilai multikulturalisme dianggap ekstra religius yang ditolak oleh para teolog Muslim, sehingga-meskipun Islam tidak bertentangan multikulturalisme_tetapi sampai sejauh ini masih belum bisa diterima prinsip-prinsip multikulturalisme oleh semua Muslim, terutama para ulama konservatif. ${ }^{6}$

Para ulama konservatif menganggap bahwa Islam adalah agama yang tidak bisa dicampuradukkan dengan tradisi dan budaya, yang dianggap merupakan hasil olah karya manusia. Sedangkan agama Islam, merupakan ajaran suci yang langsung diberikan oleh Allah melalui RasulNYA. Relasi antara agama dengan tradisi atau budaya, tidak sejalan dan bersifat relasi konfrontatif.

Tetapi sebagian ulama, tidak keberatan, jika agama mengakomodir tradisi dan budaya masyarakat. Untuk mensinergikan agama dan kultur masyarakat, Mun'im A. Sirry, menyebutnya diperlukan dua hal. Pertama, dilakukan penafsiran ulang atas doktrindoktrin keagamaan ortodoks yang sampai sejauh ini dijadikan dalih untuk bersikap ekslusif dan opresif. Penafsiran ulang teks-teks agama ini harus dilakukan untuk menghindari sikap represif oleh pemeluk agama terhadap kultur masyarakat atau kearifan tradisi lokal, dan sekaligus mengantarkan suksesnya demokrasi.

Kedua, mendialogkan agama dengan gagasan-gagasan modern. Saat ini masyarakat dihadapkan kepada dunia baru, di mana masyarakat beragama harus mampu beradaptasi dengan peradabanperadaban besar yang tidak didasarkan pada agama, seperti kultur Barat modern. Masyarakat beragama tidak mungkin menghindari dari ide-ide dan gagasan teori sekuler. Karenanya, sikap adaptif menjadi sebuah keniscayaan bagi agama Islam terhadap modernisme.

\footnotetext{
${ }^{6}$ Muhammad Yusri, Prinsip Pendidikan Multikulturalisme dalam Ajaran Agama-Agama di
} Indonesia, Jurnal: Kependidikan Islam, Vol.3, No.2, Juli-Desember 2008. 
Agama Islam tidak bisa menolak kehadiran Barat modern, tetapi harus adaptif terhadap kondisi ini. Hal ini disebabkan, derasnya arus modernisme yang masuk ke semua sendi kehidupan umat Muslim dan hampir semua umat beragama di seluruh dunia. Abdul Karim Soroush, menegaskan, bahwa umat beragama dihadapkan pada dua persoalan, local problem (problem-problem lokal) dan universal problem (problem-problem universal), yakni problem kemanusian secara keseluruhan. ${ }^{7}$ Misalnya, problem tentang hak asasi manusia, hak perempuan, telah menjadi problem global.

Inilah yang melahirkan teori bagi Soroush, yang dikenal dengan teori penyusutan dan pengembangan interpretasi agama (the contraction and expansion of religious interpretation/al qabd - wa albast), yang merupakan paradigma yang ditawarkan Soroush untuk membendung arus otoritarianisme sebuah penafsiran agama. Teori ini dipandang dapat menjadi pilar penguat pluralisme dan nilai-nilai demokrasi. Soroush mengingatkan agamawan untuk tidak terjebak dalam sebuah penafsiran agama tertentu, apalagi menobatkannya sebagai satu-satunya pemahaman keagamaan yang benar. Soroush mengingatkan, dijadikannya pemahaman agama sebagai sebuah ideologi bagi negara menyebabkan otoritarianisme agama dan dapat mengancam nilai-nilai demokrasi. ${ }^{8}$ Penerimaan agama terhadap tradisi atau budaya (relasi kompromistik), ini menyebabkan agama bisa menyesuaikan pada zamannya.

\section{Multikulturalisme dalam Ajaran Islam}

Ajaran Islam sebenarnya telah memberikan sinyal kuat untuk bisa menjalankan dimensi multikulturalisme sebagaimana pernyataan bahwa Islam adalah agama yang menebarkan kasih sayang kepada

\footnotetext{
${ }^{7}$ Abdulkarim Soroush, Reason, Freedom \& Democracy in Islam, (Paris: Unesco, 2000), 56.

${ }^{8}$ Badarussyamsi, Pemikiran Abdul Karim Soroush Tentang Persoalan Otoritas Agama, Islamica, Volume 10, Nomor 1, September 2015, 56.
} 
seluruh alam. Hal ini tentu tidak terlepas dari sifat Allah, Al Rahmân (memberikan kasih sayangnya kepada semua makhluk, tidak terkecuali apakah makhluk itu taat kepadanya atau tidak). (Q.S Al Fatihah $\{1\}: 3$.

Selain dalam teks Al-Qur'an dengan sangat meyakinkan disebutkan bahwa multikulturalisme sama sekali tidak ada pertentangan dengan ajaran Islam, dalam sunnah Rasulullah juga menunjukkan hal sama. Perintah Rasulullah dalam menghormati tamu, tidak perlu memandang tamu yang hadir di rumahnya itu. Begitu juga perintah Rasulullah dalam menghormati tetangganya, tidak perlu melihat apakah tetangganya itu beragama Yahudi, Majusi atau Nasrani, semuanya harus tetap dihormati.

Dari Abu Hurairah Radhiyallahu 'anhu, dari Rasulullah Shallallahu 'alaihi wa sallam, beliau bersabda: "Barang siapa beriman kepada Allah dan hari akhir, hendaklah ia berkata baik atau diam. Barang siapa beriman kepada Allah dan hari Akhir, hendaklah ia menghormati tetangganya. Dan barang siapa beriman kepada Allah dan hari Akhir, hendaklah ia memuliakan tamunya". [HR al-Bukhâri dan Muslim]. ${ }^{9}$

Bukan hanya itu, seperti yang tercermin dalam perilaku Rasulullah, beliau juga sangat menghormati dan menghargai eksistensi pluralitas budaya dan agama. Misalnya, bagaimana ia menghormati dan tidak memasalahkan agama lain. Di bawah ini sekilas cerita yang disarikan dari hadis Nabi, tentang penghormatan Rasulullah kepada siapapun, termasuk kepada orang lemah dan agama lain.

Pada sudut pasar Madinah Al Munawarah, ada seorang Yahudi yang buta. Hari demi hari, Rasulullah mendatanginya untuk menyuapi makanan. Bahkan, si buta tidak mengetahui bahwa yang menyuapi

\footnotetext{
${ }^{9}$ Hadits tersebut tergolong hadis shahih, periwayat hadis tersebut selain al-Bukhâri (no. 6018, 6136, 6475), Muslim (no. 47), juga Ahmad (II/267, 433, 463), Abu Dawud (no. 5154), at-Tirmidzi (no. 2500), Ibnu Hibban (no. 507, 517-at-Ta'lîqâtul-Hisân), al-Baihaqi (VIII/164).
} 
adalah Rasulullah, sehingga dari lisan si buta keluar kata-kata: "Wahai saudaraku, jangan dekati Muhammad (Rasulullah), dia itu orang gila, dia itu pembohong, dia itu tukang sihir. Apabila kalian mendekatinya, maka kalian akan di pengaruhinya."

Hampir setiap pagi, Rasulullah SAW mendatanginya dengan membawa makanan, dan tanpa berkata sepatah katapun Rasul menyuapi makanan yang dibawanya kepada pengemis itu walaupun pengemis itu selalu berpesan agar tidak mendekati orang yang bernama Muhammad.Rasulullah SAW melakukan hal itu hingga beliau menjelang wafat. Setelah Rasulullah wafat, tak ada lagi orang yang membawakan makanan setiap pagi dan yang menyuapi orang Yahudi yang buta itu.

Suatu hari Abu Bakar ra berkunjung ke rumah anaknya (Aisyah). Beliau bertanya kepada Aisyah: "Anakku, adakah sunnah Rasul yang belum aku kerjakan?" . Aisyah menjawab pertanyaan ayahnya: "Wahai ayah, engkau adalah seorang ahli sunnah saja. Hampir tidak ada satu sunnah pun yang belum ayah lakukan kecuali satu sunnah saja“, ucap Aisyah."Apakah itu?" Tanya Abu Bakar. "Setiap pagi, Rasulullah SAW selalu pergi ke ujung pasar dengan membawakan makanan untuk seorang pengemis Yahudi buta yang ada di sana", jawab Aisyah.

Keesokan harinya, Abu Bakar pergi ke pasar dengan membawa makanan untuk diberikan kepada pengemis itu. Abu Bakar mendatangi pengemis itu dan memberikan makanan itu kepadanya.Ketika Abu Bakar mulai menyuapinya, tiba-tiba pengemis itu marah sambil berteriak: "Siapa kamu" Abu Bakar menjawab: "Aku orang yang biasa". "Bukan. Engkau bukan orang yang biasa mendatangiku." sahut pengemis buta itu.

Lalu pengemis itu melanjutkan bicaranya: "Apabila ia datang kepadaku, tidak susah tangan ini memegang dan tidak susah mulut ini mengunyah. Orang yang biasa mendatangiku itu selalu menyuapiku, 
tapi terlebih dahulu dihaluskannya makanan itu, baru setelah itu ia berikan makanan itu kepadaku."

Abu Bakar yang mendengar jawaban orang buta itu kemudian menangis sambil berkata: "Aku memang bukan yang biasa datang kepadamu. Aku adalah salah seorang dari sahabatnya. Orang yang mulia itu telah tiada. Ia adalah Muhammad, Rasulullah SAW."

Setelah pengemis itu mendengar cerita Abu Bakar, pengemis itu pun menangis dan kemudian berkata "Benarkah demikian?",tanya pengemis, kepalanya tertunduk dan air matanya mulai menetes.

"Selama ini aku selalu menghinanya dan memfitnahnya", lanjutnya. Tetapi ia tidak pernah marah kepadaku, sedikitpun!", ucap sang pengemis Yahudi sambil menangis terisak.

"la selalu mendatangiku, sambil menyuapiku dengan cara yang sangat lemah lembut." sambil menahan kesedihan, namun akhirnya dia pun menangis.

Lalu di tengah tangisannya, sang pengemis Yahudi itupun berteriak, "la begitu mulia... la begitu mulia...!!!" sambil mendongakkan kepalanya kearah langit biru. Kedua tangannya dibuka lebar seperti berdoa, dan kemudian kembali duduk simpuh.

Spontan, mereka berpelukan. Mereka berdua larut dalam tangisan. Tangisan kehilangan seseorang yang paling mulia sepanjang masa. Lalu sesaat mereka terdiam, kemudian pengemis Yahudi buta itu meminta kepada Abu Bakar untuk menuntunnya bersyahadat.

Belum lagi Rasulullah selama memimpin Madinan, semua suku, ras, adat istiadat masyarakat Madinah sangat dihormati dan mendapat perlindungan dari kaum muslimin. Maka bisa dipastikan, bahwa Islam sangat menerima prinsip-prinsip multikulturalisme.

Andre Muller, menjelaskan, secara teoritik, multikultarilsme mengandaikan adanya kesadaran internal yang inklusif dan mengejewentahkan dalam perilaku sosial. Ritual puas, misalnya, idealnya dapat mengantarkan para pelakunya menemukan kesadaran 
hati nurani yang bersifat universal sehingga memiliki daya pandang egaliter terhadap sesama. Sebuah kesadaran yang mengikat kecerdasan emosi seseorang hamba dengan Tuhannya dan menjadi landasan bagi terbangunnya kecerdasan relasi rasional antarsesama. $^{10}$

Kebaikan ummat Islam bukan sekedar simbolik, karena telah mengikrarkan keyakinan Allah swt. sebagai Tuhannya dan Muhammad saw sebagai Rasulullah, tetapi karena identifikasi sebagai muslim memberikan konsekuensi untuk menunjukkan komitmennyadalam beribadah kepada Allah. Dalam Al-Qur'an, dijelaskan umat Islam memiliki komitmen, yang keduanya harus dijalankan dengan baik, yaitu "hablun min Allah wa hablun minal-naas(membangun hubungan dengan Allah dan kepada sesama manusia)“. Dan bentuk tanggung jawab sosial ummat Islam, meliputi berbagai aspek, diantaranya:

1. Menjalin silaturrahmi dengan tetangga.

2. Memberikan infak sebagian dari harta yang dimiliki, baik yang wajib maupun yang sunnah dalam bentuk sedekah (QS. Ibrahim/14:7).

3. Menjenguk bila ada anggota masyarakatyang sakit dan ta'ziah bila ada anggota masyarakat yang meninggal dengan mengantarkan jenazahnya sampai di kubur.

4. Memberi bantuan menurut kemampuan bila ada anggota masyarakat yang memerlukan bantuan.

5. Penyusunan sistem sosial yang efektif dan efisien untuk membangun masyarakat, baik mental spiritual maupun fisik material.

Dalam logika Islam, tidak cukup seseorang menjadi shaleh untuk pribadinya sendiri, sementara itu ia mengabaikan kerusakan yang dialami oleh orang lain. Sehingga menurut Islam orang-orang yang benar shaleh adalah orang yang memperbaiki dirinya dan berusaha untuk menjalin hubungan baik dengan orang lain semata-

${ }^{10}$ Andre Moller, Ramadhan di Jawa: Pandangan dari Luar, (Jakarta: Nalar, 2005), 72 
mata demi kebaikan bersama. Bukan hanya sekedar ibadah kepada Allah, tapi juga harus ibadah sosial, yang peruntukannya bagi kesejahteraan manusia lain dan makhluk lain. ${ }^{11}$

\section{Relasi Islam dan Tradisi dalam Pandangan Islam Indonesia}

Indonesia adalah salah satu Negara dengan jumlah penduduk muslim besar di dunia. Menurut hasil survey pada tahun 2000 mencatat bahwa jumlah ummat islam di negeri ini berada pada angka $88,22 \%$, sebuah prosentasi yang tinggi sekali. ${ }^{12}$ Di lain sisi, Indonesia juga dikenal sebagai Negara dengan keanekaragaman masyarakatnya. Dengan bahasa lain, Indonesia adalah bangsa yang majemuk, hidup bermacam agama, etnis, dan kelompok-kelompok sosial yang dimiliki.

Kemajemukan merupakan realitas yang tak terbantahkan di bumi Nusantara ini. Sehingga sering dilukiskan, di Indonesia terdapatlebih dari tiga ratus kelompok etnis yang berbeda-beda, masing-masing kelompok mempuyai identitas budayanya sendiri-sendiri, dan lebih dari dua ratus lima puluh bahasa yang berbeda-beda dipakai oleh penduduknya serta hampir semua agama besar dunia diwakili, selain dari agama-agama asli yang jumlahnya banyak sekali. Masyarakat plural (plural society) adalah suatu masyarakat yang terdiri dari dua atau lebih elemen dan tatanan sosial yang hidup berdampingan, tetapi tidak berintegrasi dalam satu kesatuan politik. Karena itulah, agama, etnik, dan kelompok sosial lainnya sebagai instrumen dari kemajemukan masyarakat Indonesia bisa menjadi persoalan krusial bagi proses integrasi sosial. Menurut Syamsul Arifin, dalam kehidupan sesungguhnya tidak cukup hanya berkecupan secara ekonomi, tetapi

\footnotetext{
${ }^{11}$ Yusuf Al Qardhawi, Menuju Pemahaman Islam Yang Kaffah Analisis Komprehensif tentang Pilar, Karakteristik, Tujuan, dan Sumber-Sumber Acuan Islam, (Jakarta: Insan Cemerlang, 2003), 350

${ }^{12} \mathrm{M}$. Din Syamsyuddin, Etika Agama Islam dalam Membangun Masyarakat Madani, (Jakarta: Logos Wacana IImu, 2000), 195.
} 
lebih dari itu membangun hubungan antarmanusia adalah menjadi hal yang tidak kalah penting. ${ }^{13}$ Keanekaragaman itu, seharusnya menjadi sebuah kekuatan—bukan justru memporak-porandakan sebuah kekuatan. ${ }^{14}$

Misalnya, bagaimana tradisi "megengan"15 (penghormatan oleh orang-orang Islam di Jawa) dalam menyambut bulan ramadhan. Tradisi megengan memang menjadi sesuatu yang khas bagi Islam Jawa. Tradisi yang biasa dilaksanakan menjelang puasa oleh Islam Jawa ini, tidak dimiliki oleh Islam lain, selain Jawa. Sama dengan tradisi-tradisi lain di dalam Islam Jawa, maka tradisi ini juga tidak diketahui secara pasti siapa yang menciptakan dan mengawali pelaksanaannya. Tetapi tentu ada dugaan kuat bahwa tradisi ini diciptakan oleh walisanga khususnya Kanjeng Sunan Kalijaga. Memang hal ini baru sebatas dugaan, namun mengingat bahwa kreasikreasi tentang Islam Jawa terutama yang menyangkut tradisi-tradisi baru akulturatif yang bervariatif tersebut kebanyakan datang dari pemikiran Kanjeng Sunan Kalijaga, maka kiranya dugaan ini pun bisa dipertanggungjawabkan.

Para walisanga dalam mengajarkan Islam lebih banyak dilakukan melalui simbol-simbol budaya. Sayangnya, belakangan ini masyarakat sering menangkap simbolnya belaka, tetapi menanggalkan

\footnotetext{
${ }^{13}$ Syamsul Arifin, Studi Agama: Perspektif Sosiologi dan Isu-isu Kontemporer, (Malang: UMM Press, 2009), 77.

${ }_{14}$ Idrus Ruslan, Dimensi Kearifan Lokal Masyarakat Lampung Sebagai Media Resolusi Konflik, (Lampung: Prosceeding of the 16th Annual International Conference on Islamic Studies-AICIS, 2016), 50.

${ }^{15}$ Megengan secara lughawi berarti menahan. Misalnya dalam ungkapan megeng nafas, artinya menahan nafas, megeng hawa nafsu artinya menahan hawa nafsu dan sebagainya. Di dalam konteks puasa, maka yang dimaksud adalah menahan hawa nafsu selama bulan puasa. Secara simbolik, bahwa upacara megengan berarti menjadi penanda bahwa manusia akan memasuki bulan puasa sehingga harus menahan hawa nafsu, baik yang terkait dengan makan, minum, hubungan seksual dan nafsu lainnya. Dengan demikian, megeng berarti suatu penanda bagi orang Islam untuk melakukan persiapan secara khusus dalam menghadapi bulan yang sangat disucikan di dalam Islam. Para walisanga memang mengajarkan Islam kepada masyarakat dengan berbagai simbol-simbol. Dan untuk itu maka dibuatlah tradisi untuk menandainya, yang kebanyakan adalah menggunakan medium slametan meskipun namanya sangat bervariasi. (http://nursyam.uinsby.ac.id, Artikel Nur Syam, Tradisi Megengan di Jawa),
} 
substansinya. Dalam simbol budaya sesungguhnya ada substansi mendasar yang bisa diambil. Misalnya tradisi megengan, secara substansial merupakan simbolisasi bahwa puasa adalah hari di mana seseorang harus menahan nafsu. Dengan demikian, berbagai macam tradisi yang berkembang dan hidup di dalam masyarakat khususnya-masyarakat Jawa tidak boleh dipandang dari sudut asli atau tidak ketidakaslian ajaran Islam, tetapi seharusnya dibaca bahwa memang ada varian-varian di dalam mengekspresikan Islam itu melalui tradisi yang dikonstruksi oleh mereka sendiri.

Megengan hanyalah satu dari sekian banyak contoh tentang terjadinya akulturasi budaya dengan agama. Tetapi sayangnya, akulturasi budaya dengan agama, bagi sebagian muslim dianggap sebagai agama yang menyimpang dan perlu diluruskan. Tetapi Indonesia yang dipenuhi oleh tradisi, seharusnya agama bisa masuk sebagaimana terjadinya akulturasi budaya dengan agama yang terjadi sekarang ini.

Bercermin dari kenyataan yang sudah ada, dengan keanekaragaman yang dimiliki di atas, Indonesia menjadi satu diantara negara yang memiliki pengalaman hitam dalam proses pengelolaan keanekaragamannya. Konflik berbau SARA selalu menjadi tantangan yang sangat serius bagi bangsa Indonesia yang majemuk ini. Dengan kata lain, kemajemukan di Indonesia masih sering menjadi sumber ketegangan sosial. Multikulturalisme adalah sebuah ideologi yang menekankan kesederajatan dalam perbedaan-perbedaan kebudayaan. Multikulturalisme juga mendasarkan diri pada pengakuan terhadap minoritas. Multikulturalisme berdiri dalam ketegangan antara hak untuk diperlakukan sama di hadapan hukum dan interpretasi atas hak-hak bangsa atas perkembangan dirinya. ${ }^{16}$

Multikultur dan beragamnya agama di Indonesia, tentu tidak bisa kemudian agama Islam dengan menggunakan wilayah "syar'i" nya

\footnotetext{
${ }^{16}$ Willy Kimlicka, Kewargaan Multikultural, (Jakarta: LP3ES, 2003), 12 .
} 
memaksakan tradisi masyarakat tertentu (sebut misalnya tradisi di Jawa) kemudian dijadikan satu kesatuan utuh dengan mengubah tradisi menjadi tradisi Islam (ke-Arab-Araban). Karenanya, relasi Islam dengan tradisi di Indonesia sampai sejauh ini yang paling tepat adalah relasi Islam-Tradisi yang kompromistik, bukan relasi Islam-Tradisi yang konfrontatif.

Contoh lain yang pernah disampaikan KH Abdurrahaman Wahid (Gus Dur) dalam tulisannya berjudul Tombo Ati Berbentuk Jazz, Gus Dur menyebut, syiiran "Tonbo Ati" adalah sajak berbahasa Arab hasil karya Sayyida Ali (sepupu Rasulullah Muhammad). Oleh KH. Bisri Musthofa dari Rembang (ayah KH. A. Musthofa Bisri), diterjemahkan ke dalam bahasa Indonesia dengan judul "Tombo Ati". ${ }^{17}$

\section{E. Penutup}

Sikap Islam terhadap multikulturalisme tidak pernah menolak dan bahkan menempatkan pada posisi yang tinggi. Hubungan manusia dengan Tuhannya dan hubungan manusia dengan manusia lain sangat ditekankan dalam agama Islam. Bahkan, Allah menggantungkan sikapnya dalam menilai seseorang itu baik atau tidak, digantungkan pada seberapa baik hubungan manusia dengan manusia atau sesama makhluk lainnya. Inilah yang disebut lain sebagai 'Islam rahmatan lil alamin', yaitu Islam yang memberikan manfaat dan kasih sayang kepada alam—bukan Islam yang menolak atau menebar kebencian.

Bagaimana Islam Indonesia dalam menyikapi multikulturalisme, sebagian besar masyarakat muslim mampu beradaptasi atau mengambil sikap kompromistik terhadap multukulturalisme, tetapi sebagian kecil muslim mengambil sikap berlawan, yaitu tidak mau beradaptasi dengan paham multikultural. Bagaimana seharusnya,

\footnotetext{
${ }^{17}$ Abdurrahman Wahid, Tombo Ati Berbentuk Jazz, Koran Kedaulatan Rakyat, edisi 6 Juni 2003. Lebih lengkat bisa baca Abdurrahman Wahid, Islamku, Islam Anda, Islam Kita, (Jakarta: The Wahid Institut, 2006), 261-264.
} 
melihat beragamnya masyarakat Indonesia, seharusnya seluruh muslim Indonesia mampu beradaptasi dengan multikulturalisme.

\section{DAFTAR PUSTAKA}

Al Qardhawi, Yusuf, Menuju Pemahaman Islam Yang KaffahAnalisis Komprehensif tentang Pilar, Karakteristik, Tujuan, dan SumberSumber Acuan Islam. Jakarta: Insan Cemerlang, 2003.

Arifin, Syamsul, Studi Agama: Perspektif Sosiologi dan Isu-isu Kontemporer. Malang: UMM Press, 2009.

Azra,Azyumardi, Identitas dan Krisis Budaya: Membangun Multikulturalisme Indonesia, 2017, http://www.konggresbud.budpar.go.id.

Badarussyamsi, Pemikiran Abdul Karim Soroush Tentang Persoalan Otoritas Agama, Islamica, Volume 10, Nomor 1, September 2015.

http://www.hull2017.co.uk/theboard/professor-lord-bhikhu-parekh.

http://www.psbps.org/index.php?option=com_conten\&task, posted 12 November 2008.

https://almanhaj.or.id/3347-etika-orang beriman ucapan yang baik memuliakan tetangga dan menghormati tamu.html. Diunduh tanggal 22 Mei 2017.

Kimlicka, Willy, Kewargaan Multikultural. Jakarta: LP3ES, 2003.

Mahajan, Gurpreet, Demokracy, Difference and Justice. Terj. Jakarta:Lahore: Longman and Co, 1998.

Martono, Nanang, Perubahan Sosial: Perspektif Klasik, Modern, Posmodern, dan Poskolonial. Jakarta: Rajawali Pers, 2016.

Moller, Andre, Ramadhan di Jawa: Pandangan dari Luar. Jakarta: Nalar, 2005.

Nur Syam, Tradisi Megengan di Jawa. http://nursyam.uinsby.ac.id.

Ruslan,Idrus, Dimensi Kearifan Lokal Masyarakat Lampung Sebagai Media Resolusi Konflik. Lampung: Prosceeding of the 16th Annual International Conference on Islamic Studies-AICIS, 2016. 
Soroush,Abdulkarim, Reason, Freedom \& Democracy in Islam. Paris: Unesco, 2000.

Syamsyuddin, M. Din, Etika Agama Islam dalam Membangun Masyarakat Madani. Jakarta: Logos Wacana IImu, 2000.

Yusri,Muhammad,Prinsip Pendidikan Multikulturalisme dalam Ajaran Agama-Agama di Indonesia, Jurnal: Kependidikan Islam, Vol.3, No.2, Juli-Desember 2008.

Wahid,Abdurrahman,Tombo Ati Berbentuk Jazz, Koran Kedaulatan Rakyat, edisi 6 Juni 2003.

------, Islamku, Islam Anda, Islam Kita. Jakarta: The Wahid Institut, 2006. 